\title{
Social networks that made a revolution in recruitment
}

\author{
Krinitcyna Zoya Vasilievna \\ Associate Professor \\ Tomsk Polytechnic University \\ Tomsk, 634021, Russia \\ zoya.tpu@gmail.com
}

\author{
Al-Kassab Ali Abdulkarim Reda \\ Student \\ Tomsk Polytechnic University \\ Tomsk, 634030, Russia \\ Kopilevitch Valeria Vadimovna \\ Associate Professor, \\ Tomsk State University, \\ Tomsk, 634050, Russia \\ vkopi@rambler.ru
}

\begin{abstract}
It is shown that recruitment through social networks is the new trend in human resource management. The classification of social networks usage for finding candidates is shown, analysis of networks features and usefulness for the recruiter is given. The technology of search of the candidate using social networks is developed. The analysis of the experience of using social networks in recruitment is given and their strengths and weaknesses are identified.
\end{abstract}

Keywords: social networking, recruiting, recruitment, vacancies, professional communities, jobs, professional network, search, employer, employee, search criteria, targeted sites.

\section{USE OF SOCIAL NETWORKS IN STAFF RECRUITING}

M. Zuckerberg founded one of the most popular social network Facebook in 2004. Since then there have been other social networks and they have become extremely popular for people to communicate, erasing the language, professional and geographical barriers.

Progressive companies did not miss the opportunity to use social networks and become their active users in solving HR tasks (HR - human resources) and in recruitment. Now recruiting personnel through social networks is a new trend in the field of human capital management. Company, effectively developing work on social networks, receives significant competitive advantages in recruiting and attracting qualified professionals. These advantages are related to the fact that social networks provide HR specialist with much detailed information about the candidate for the vacant position than a CV and job sites. They have a variety of information not only about the professional qualities of the applicant, but also information about the social circle, lifestyle, personal preferences and life values. By analyzing this information, you can more safely assume the suitability of this applicant for future positions even before meeting him.

In addition, social networks provide the opportunity to establish contact not only with actively seeking employment candidates, but also with those who are successfully employed and are not looking for another job, but are of interest for the company. This allows you to attract skilled professionals to create a personnel reserve for the future.

According to the forecasts of the leading Russian recruitment agencies, social networking sites should take by 2020 a leading position in the recruiting. Then the recruitment process will become significantly faster, cheaper and more efficient.

\section{TYPES OF SOCIAL NETWORKS AND THEIR USE IN RECRUITMENT}

Many successful HR managers use not only proven portals for job search, such as Rabota.ru, SuperJob and HeadHunter etc., but also take social networks as a tool of recruitment of professionals and work with them actively. The following candidates are considered: those who are actively searching for a job, and those who are not currently looking for work, but are of interest for the company. Let us highlight the main social networks that you can use when searching for candidates in Russia (table 1).

TABLE I. TYPES OF SOCIAL NETWORKS

\begin{tabular}{|l|l|l|l|l|l|}
\hline \multicolumn{2}{|c|}{ Public } & \multicolumn{2}{c|}{ Professional } & \multicolumn{2}{c|}{ Blogs } \\
\hline Network name & $\begin{array}{c}\text { Number } \\
\text { of users } \\
\text { in } \\
\text { Russia } \\
\text { (millions } \\
\text { of } \\
\text { people })\end{array}$ & $\begin{array}{c}\text { Network } \\
\text { name }\end{array}$ & $\begin{array}{c}\text { Number } \\
\text { of users } \\
\text { in } \\
\text { Russia } \\
\text { (millions } \\
\text { of } \\
\text { people })\end{array}$ & $\begin{array}{c}\text { Network } \\
\text { name }\end{array}$ & $\begin{array}{c}\text { Number } \\
\text { of users } \\
\text { in } \\
\text { Russia } \\
\text { (millions } \\
\text { of } \\
\text { people } \text { ) }\end{array}$ \\
\hline $\begin{array}{l}\text { Vkontakte } \\
\text { (vk.com) }\end{array}$ & 70,0 & LinkedIn & $\begin{array}{c}0,66 \\
(150 \\
\text { globally) }\end{array}$ & Twitter & $\begin{array}{l}1,8 \\
\text { (globally } \\
500)\end{array}$ \\
\hline Odnoklassniki & 42,6 & Professionaly & 3,0 & LiveJournal & 2,6 \\
\hline Moy mir & 40,0 & E-xecutive & 0,24 & & \\
\hline Facebook & 6,0 & Moy krug & 7,0 & & \\
\hline Instagram & $\begin{array}{l}750 \\
\text { globally) }\end{array}$ & & & & \\
\hline
\end{tabular}

Network "Vkontakte" is mainly intended for a younger audience, is popular among students with no work experience 
(54\%), health workers (25\%) and journalists (21\%). Every day site has more than 70 million visitors, among them are mostly students of Russian universities and young specialists.

The network "Odnoklassniki" is popular among residents of Russia from the age of 14, however, the bulk of the visitors are people over 40 and $75 \%$ of them are women.

In Facebook professional communities are created that are ready base for searching the employee with specific characteristics.

Network Instagram is popular among women (68\% to $32 \%$ ) and among youth (90\% of users are under 35 years old) and has greater success among the urban dwellers than the population of small towns and rural areas.

LinkedIn is a professional social network that is most convenient for the candidate search. People who are registered in LinkedIn are prepared for professional communication and exchange of experience, they are also interested in new job offers and building their careers.

Network "Professionaly" unites about 3 million people in Russia - specialists and managers from different sectors of Russian business.

Russian analogue of LinkedIn is the network "Moy krug", which allows you to search for people based on the recommendations of colleagues from the field of personnel management or recruitment agencies.

In Twitter it is best to have the corporate account of the company and to place information about vacancies which are the most important, for example, the title of the position, the estimated level of wage, career prospects and other benefits. Description cannot exceed 140 characters.

The opinions of recruiters clearly demonstrate that social networks are a tool that works in combination with classical methods of selection (table 2).

TABLE II. USE OF SOCIAL NETWORKS FOR RECRUITMENT

\begin{tabular}{|c|c|c|}
\hline Social network & Network features & $\begin{array}{l}\text { Usefulness for } \mathrm{HR} \\
\text { specialist }\end{array}$ \\
\hline Vkontakte & $\begin{array}{l}\text { You can monitor the } \\
\text { activity of friends, } \\
\text { communities through the } \\
\text { news feed; use messages } \\
\text { with photos, audio, video } \\
\text { files; to conduct surveys. }\end{array}$ & $\begin{array}{l}\text { More than } 60 \text { million } \\
\text { active communities }\end{array}$ \\
\hline Odnoklassniki & $\begin{array}{l}\text { Information is highly } \\
\text { "viral" }\end{array}$ & $\begin{array}{l}\text { Private correspondence } \\
\text { between users. }\end{array}$ \\
\hline Moy mir & $\begin{array}{l}\text { You must have mail to } \\
\text { Mail.ru. } \\
\text { You can post your photos } \\
\text { and videos. }\end{array}$ & $\begin{array}{l}\text { You can create a } \\
\text { personal blog and read } \\
\text { blogs of the other users. }\end{array}$ \\
\hline Facebook & $\begin{array}{l}\text { Virtual winks, photo } \\
\text { albums and wall for } \\
\text { messages. Drawback - a } \\
\text { complex interface. }\end{array}$ & $\begin{array}{l}\text { The bulk of its users - } \\
\text { managers of certain } \\
\text { businesses, marketers } \\
\text { and IT specialists. } \\
\text { For contacts with } \\
\text { business partners abroad. }\end{array}$ \\
\hline Instagram & $\begin{array}{l}\text { You must download a } \\
\text { special application; photo } \\
\text { adding is only via } \\
\text { smartphone. }\end{array}$ & $\begin{array}{lll}\text { Visual design } & \text { of } \\
\text { vacancies } & & \end{array}$ \\
\hline
\end{tabular}

\begin{tabular}{|c|c|c|}
\hline LinkedIn & $\begin{array}{l}\text { There are companies, } \\
\text { people, interest groups. } \\
\text { Establishing business } \\
\text { contacts and search of } \\
\text { partners abroad. } \\
\text { Distribution or obtaining } \\
\text { professional advice. }\end{array}$ & $\begin{array}{l}\text { View the profiles. } \\
\text { Publish a professional } \\
\text { resume. } \\
\text { Advertise vacancies and } \\
\text { look for work. } \\
\text { Recommend and to be } \\
\text { recommended. } \\
\text { View reviews and } \\
\text { confirming the skills of } \\
\text { an employee. }\end{array}$ \\
\hline Professionaly & $\begin{array}{l}\text { You can create a contact } \\
\text { list of professional } \\
\text { acquaintances, enter into } \\
\text { branch, regional and } \\
\text { corporate community, } \\
\text { make blog posts on } \\
\text { business topics, post job } \\
\text { vacancies, CVS, advertise. }\end{array}$ & $\begin{array}{l}\text { Communication in } \\
\text { communities } \\
\text { and publishing posts in } \\
\text { the already existing } \\
\text { professional } \\
\text { associations. } \\
\text { You can open a group or } \\
\text { company page and } \\
\text { publish job offers and } \\
\text { import portals on job } \\
\text { search. }\end{array}$ \\
\hline $\begin{array}{c}\text { E-xecutive } \\
\text { (Russian senior } \\
\text { and middle } \\
\text { management) }\end{array}$ & $\begin{array}{l}\text { The information entered by } \\
\text { the user is checked for a } \\
\text { long time (for two weeks). } \\
\text { You can exchange private } \\
\text { messages and create } \\
\text { groups of interest. }\end{array}$ & $\begin{array}{l}\text { Community has a limit } \\
\text { of not less than two years } \\
\text { of experience. } \\
\text { Reading other blogs. }\end{array}$ \\
\hline Moy krug & $\begin{array}{l}\text { You can find classmates, } \\
\text { fellow students. Exchange } \\
\text { personal messages, keep } \\
\text { track of recommendations. }\end{array}$ & $\begin{array}{l}\text { Posting vacancies, } \\
\text { resumes. }\end{array}$ \\
\hline Twitter & 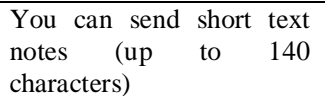 & Rarely used \\
\hline LiveJournal & $\begin{array}{l}\text { All users and anonymous } \\
\text { users can publish and } \\
\text { comment on other people's } \\
\text { blog posts, create and } \\
\text { maintain collective blogs } \\
\text { (community) }\end{array}$ & $\begin{array}{l}\text { Blogging and/or } \\
\text { community companies. } \\
\text { Communication in a } \\
\text { narrow professional } \\
\text { community. }\end{array}$ \\
\hline
\end{tabular}

Of course the question arises what social networks are most effective in finding candidates. Studies show [2] that the largest number of votes is for LinkedIn $(41 \%)$. Quite a large number of respondents called "Vkontakte" $(25 \%)$, and with the help of network Professionaly $7 \%$ is looking for candidates, and 5\% prefer Facebook, $18 \%$ prefer other social networks. However, popularity of this or that service from recruiters does not mean that this community will help you personally to successfully find a candidate. The best option is to look for the right candidate at niche sites in a large community. Then the audience to search becomes much wider and the probability of finding the right person is increased.

\section{THE TECHNOLOGY OF SEARCHING FOR CANDIDATES IN SOCIAL NETWORKS}

It is better to use a professional networks for targeted recruiting - a space which involves not only community interest but a professional reports from the field of activity of the respondent. But it is not so simple. Even if a professional of a high level is in sight and is active on the network, the chances of success when searching directly in the list of candidates can be not very large for the recruiter. We need a clear algorithm of actions. The proposed technology of searching for the candidate (fig. 1) will significantly improve search performance. 


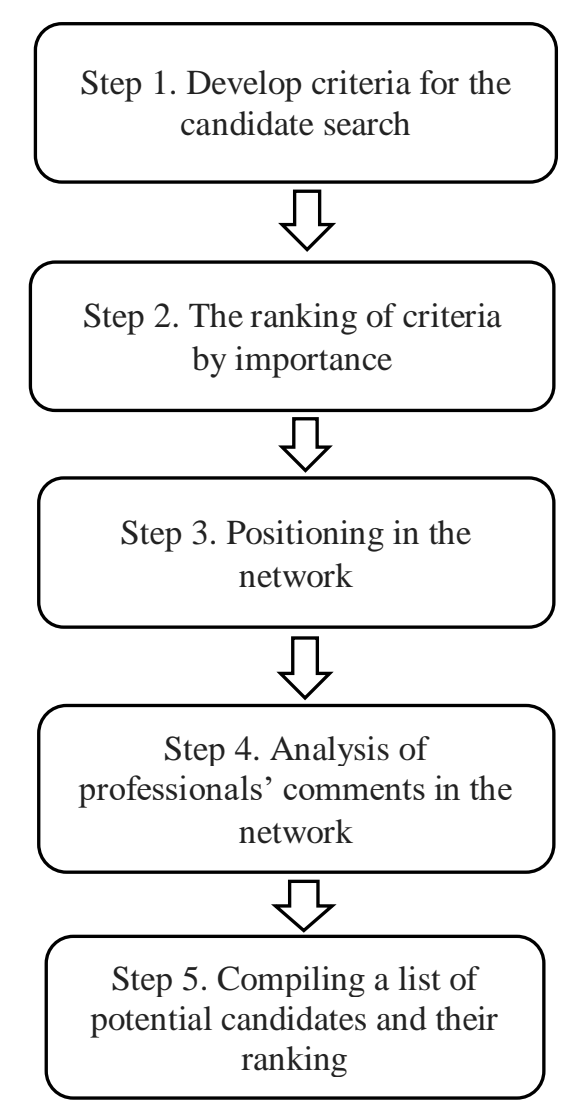

Fig. 1. Technology of the candidate search on the social network

Search criteria may be region, industry, firm size, work experience, participation in projects, remoteness from office, the performance criteria for the candidate, the main objectives and other characteristics. The applicant must also understand what he wants, and he should have his own search criteria.

The ranking of search criteria according to the degree of decreasing of their significance is necessary to select one or another social network. For example, if a relation to a particular territory is important, you should apply to regional analogs of global social networks. If you need a worker only for the implementation of the project, then you can apply to areas or sites on project management or to freelancers.

Proper positioning serves the professional interest to all materials and provokes an active discussion in the network. Corporate website is not enough for these purposes because people want an informal and direct communication with the employer.

Analysis of comments of professionals in the social network helps determine the extent of their professional training, their ability to reasoning, attitude towards criticism, etc.

The list of potentially interesting candidates and ranking them in order of attractiveness allows you to find the right candidate for the company.
It should be noted that you should not go "too far" when finding a candidate. Too active searching will work against the employer, as professionals will not want to apply for a job for which too many candidates from professional societies are considered.

\section{THE ANALYSIS OF THE EXPERIENCE OF USING SOCIAL NETWORKS IN RECRUITMENT}

In Russia there is some albeit small experience using social networks in recruiting staff. And it shows the new possibilities opening up in front of HR-specialist for recruitment, as well as the difficulties of using a new tool of personnel work. Let us consider some of the results of this experiment.

1. Return wasted resources due to the accurate selection and a long, productive work of the employee in the company.

An analysis of the use of social media in recruitment in one of the Russian recruitment companies [1] showed that there were $15 \%$ fewer staff replacements for customers. This suggests that a detailed study of the candidate profile with the help of social networks allows to determine its compliance with the corporate culture, general level of intelligence, as well as ability to quickly get feedback from previous employers.

2. This is a "surgical" tool to solve specific HR challenges.

When it became necessary to find a chess player to teach kids in the chess club, the first thing was to publish a vacancy on the job portals. Responses were minimal, and then it was decided to involve the professional community in popular social networks. To our surprise, there were a great many. Disregarding communities for chess lovers (a specialist with education was needed), a university was selected. There was a request directly addressed to the master of the game of chess with special education and teaching experience. The results of this experiment: great reviews of little customers and cooperation with a unique specialist, which has continued for more than five years [2].

3. Social networks are a tool that works in combination with classical methods of selection.

A company "Work Service" decided to conduct a study and figure out how active and productive the russian recruiters use social networks. The survey was conducted among professionals from different business sectors: consulting, real estate, construction, development, IT and telecommunications, industrial equipment, retail, finance, FMCG, energy, oil and gas industry, media industry, recruitment [3]. The results were as follows:

- $42 \%$ of respondents replied with a categorical "no" to using only this method.

- $52 \%$ believe that recruiting in these services must be combined with other tools (websites dedicated to job searching, professional communities, recommendations, recruiting agencies, media, private company pages, personal contacts and the help of friends).

- $36 \%$ of the surveyed experts consider the internet communities nowadays as one of the main tools for the modern recruiter. 
4. Social networking is a great tool for building a trusting dialogue with potential applicants during the formation of HRbrand of the company.

In the company "3M Russia" social networks are a formal and a valuable tool for employer branding, the use of which allows to be where the target audience is and to interact with them [4].

Summing up the analysis of the experience of the use of social media in the work of a recruiter it is possible to note their characteristic advantages and disadvantages (table 3 ).

TABLE III. THE ADVANTAGES AND DIS ADVANTAGES OF RECRUITING STAFF VIA SOCIAL NETWORKS

\begin{tabular}{|l|l|}
\hline \multicolumn{1}{|c|}{ Advantages } & \multicolumn{1}{|c|}{ Disadvantages } \\
\hline $\begin{array}{l}\text { Targeted candidate search (you can } \\
\text { search for people of certain } \\
\text { professions, companies, including in } \\
\text { other cities and countries) }\end{array}$ & $\begin{array}{l}\text { Large time and human costs for } \\
\text { staff search in social networks }\end{array}$ \\
\hline $\begin{array}{l}\text { Detailed portfolio and projects of the } \\
\text { candidate }\end{array}$ & $\begin{array}{l}\text { Closing page for strangers (non- } \\
\text { friends) or providing minimal } \\
\text { information (if the person does not } \\
\text { want to tell about yourself anything } \\
\text { extra) to form a complete picture of } \\
\text { the candidate; }\end{array}$ \\
\hline $\begin{array}{l}\text { Job requests from a specialists } \\
\text { motivated to work for the company } \\
\text { if it is successfully working on its } \\
\text { HR-brand fommunication in professional } \\
\text { Recommendation from former } \\
\text { employer, proof of professional } \\
\text { competence }\end{array}$ & $\begin{array}{l}\text { Not every candidate has an account } \\
\text { in social networks }\end{array}$ \\
\hline $\begin{array}{l}\text { The ability to recommend friends, } \\
\text { colleagues, acquaintances and } \\
\text { relatives for the job }\end{array}$ & $\begin{array}{l}\text { The lack of knowledge of search } \\
\text { techniques in social networks }\end{array}$ \\
\hline
\end{tabular}

\section{FORECAST FOR THE DEVELOPMENT OF SOCIAL NETWORKS}

As shown by many studies, the development of social networks in Russia will be active in the next few years. The number of social networks to find qualified personnel is likely to increase. However, due to the increased competition between the networks only the most popular networks will remain in the labor market and their number will be small.

Large companies will likely use their own internal social networks more actively. This will allow them to more efficiently manage their internal labor market, to attract and retain qualified personnel.
The development of Internet resources and means of communication also leads to the fact that large companies can conduct their own remote search, evaluation and selection of candidates in different regions of Russia. Commonplace, for example, will be a remote interview via Skype or by other means.

Social recruitment will be developed by creating an attractive HR brand of the company using online resources. In the future candidates will begin to contact the organization even with closed vacancies.

All of these trends of social recruiting will positively affect the work of HR managers who will gradually learn to understand the candidate profile from the point of view of interpretation of professional and personal characteristics.

\section{REFERENCES}

[1] Petrovicheva S.V. Podbor personala s pomoshh'ju social'nyh setej. /Upravlenie chelovecheskim kapitalom, 2015, № 3-4, s.218-223.

[2] Bryksina V.D. Uluchshaem kachestvo podbora s pomoshh'ju social'nyh setej. /Upravlenie chelovecheskim kapitalom, 2015, № 3-4, s.208-217.

[3] Ananjan G.A. Rekruting cherez social'nye seti: sekret uspeha. /Upravlenie chelovecheskim kapitalom, 2014, № 4, s.304-313.

[4] Nazarova A. Issledovanie: auditorija social'nyh setej v Rossii. http://www.likeni.ru/events/Issledovanie-auditoriya-sotsialnykhsetey-vRossii-.

[5] Social'nye seti i virtual'nye setevye soobshhestva: Sb. nauch. trudov / Otv. red. L.N. Verchenov, D.V. Efremenko, V.I. Tishhenko. - M.: INION RAN, 2013. - $360 \mathrm{~s}$.

[6] Vishnjakova M.V. Social'naja set' kak instrument poiska tolkovyh rabotnikov. / Upravlenie chelovecheskim kapitalom, 2013, № 3, s.242247.

[7] Ignatkina V.V. Social'nye seti v sovremennom rekrutinge. /Mediaskop, 2012, №2

[8] Bernie Borges. How Social Technology Is Transforming the Modern Recruitment Process. - http://www.socialmediatoday.com/socialbusiness/how-social-technology-transforming-modern-recruitmentprocess-podcast.

[9] Nicole Fallon Taylor. What's Next for Recruiting? http://www.businessnewsdaily.com/6975-future-ofrecruiting.html\#sthash.1p8DnTgh.dpuf.

[10] THE FUTURE OF SOCIAL MEDIA AND MOBILE RECRUITMENT - http://www.cdicorp.com/future-social-media-mobile-recruitment/.

[11] How Nestle uses social media for recruitment. http://linkhumans.com/blog/how-nestle-use-social-media-forrecruitment/ 